\title{
PROCURADORIA FISCAL DO MUNICÍPIO DO RECIFE: UM ESTUDO SOBRE SUA ORGANIZAÇÃO, ESTRUTURA E FUNCIONAMENTO
}

\section{PROSECUTOR FISCAL REEF CITY: A STUDY OF YOUR ORGANIZATION, STRUCTURE AND FUNCTIONING}

\author{
Hélio Silvio Ourém Campos ${ }^{1}$ \\ Alberes José Quintans de Freitas Júnior ${ }^{2}$
}

\begin{abstract}
Resumo
O presente trabalho estuda a Procuradoria do Município do Recife, com foco sobre a Procuradoria Fiscal, visando compreender sua estrutura, organização e função, bem como as atividades realizadas pelo Procurador Municipal, entendendo, assim, sua finalidade e importância para o ente municipal e a sociedade. Através do método de pesquisa bibliográfica descritiva, analisamos a estrutura desse órgão, apresentando um pouco de sua história, e das principais medidas apresentadas por seu dirigente, frente ao cenário atual do Poder Judiciário, e das prerrogativas de função garantidas pelo Novo Código de Processo Civil. Dessa forma, objetivamos fazer um estudo do processo a partir da perspectiva com foco sobre a atuação dos agentes processuais a fim de contribuir para a valorização dessa classe. Como conclusão, podemos constatar a falta de publicidade diante deste importante agente de controle fiscal, e, o esforço realizado no sentido de buscar a valorização deste órgão, dada a sua vitalidade para a Administração Pública.
\end{abstract}

Palavras-chaves: Advocacia Pública Municipal; Administração Pública; Tributos.

\section{Abstract}

This paper studies the Attorney of the City of Recife, with focus on Tax Attorney, to understand its structure, organization and function, as well as the activities carried out by the Municipal Prosecutor, understanding, thus, its purpose and importance to the municipal entity and society. Through the descriptive literature search method, we analyzed the structure of this body, with a bit of its history, and the main measures presented by its leader, against the current backdrop of the Judiciary, and the function prerogatives guaranteed by the new Civil Procedure Code. Thus, we aim to make a case study from the perspective focusing on the performance of procedural staff to contribute to the development of this class. In conclusion, we note the lack of publicity on this important tax control agent, and the effort made in order to seek the recovery of this body, given its vitality for Public Administration.

Keywords: Municipal Public Attorneyship; Public Administration; Taxation.

\footnotetext{
${ }^{1}$ Líder de Grupo de Pesquisa - CNPq: "Processo tributário: sonegação fiscal e direitos humanos". Professor da Escola Superior da Magistratura de Pernambuco. Professor Titular e Membro do Conselho Superior da Universidade Católica de Pernambuco (Graduação, Mestrado e Doutorado). Pós-doutorado pela Universidade Clássica de Lisboa. E-mail: ouremcampos@jfpe.gov.br

${ }^{2}$ Bacharel pela Universidade Católica de Pernambuco. E-mail: vania.souza@jfpe.jus.br
} 


\section{INTRODUÇÃO}

A pesquisa aborda a estrutura, funcionamento e organização da Procuradoria Fiscal do Município do Recife - órgão responsável pela representação judicial do ente municipal diante das causas fiscais em que for parte, bem como a atuação dos Procuradores Municipais e sua função para a sociedade.

O tributo é a força que impulsiona o Estado Social. Nosso país é regido por uma Constituição que garante direitos básicos a todos que vivem sob a tutela do Estado. A fim de garantir tais direitos, é necessária a verba - a qual, nos moldes do Estado atual, é arrecadada, principalmente, através da cobrança de tributos. Dessa forma, garantir essa arrecadação é imprescindível para a saúde da federação e a proteção dos direitos constitucionais.

É também do espírito da Constituição de 1988, o movimento municipalista, garantindo a este ente federativo maior autonomia sobre suas políticas tributárias, conforme disciplinado em seu art. 30.

Analisaremos a estrutura da Procuradoria do Município do Recife, com foco sobre a Procuradoria Fiscal, conhecendo um pouco mais de sua história, e das principais medidas tomadas pela gestão atual do órgão.

Embora seja um órgão de importante atuação na manutenção do Estado Social, verifica-se que ainda é muito pouco estudado no meio acadêmico, e até mesmo desconhecido por grande parcela da sociedade.

As atividades do procurador não se limitam à mera promoção da arrecadação de tributos não pagos - pelo contrário, vão muito além disso, auxiliando a Administração Pública na elaboração de políticas públicas e garantindo a observância dos requisitos legais nas atividades de seus gestores.

Ser procurador significa, assim, ser um instrumento de promoção de justiça, tão importante para o Estado, quanto outros cargos políticos. Apesar disso, esses agentes públicos não têm seu trabalho devidamente divulgado ao público. Como pode assim o corpo social lutar por seus direitos quando desconhece os meios pelos quais pode se fazer ouvir?

A obscuridade por sobre a atuação desse órgão é tamanha, que se mostrou difícil, inclusive, a busca por bibliografia sobre o tema, o que não nos deve fazer esmorecer, mas lutar com mais afinco pela divulgação dessa classe, favorecendo seu trabalho e intensificando a luta pela sociedade para a garantia e proteção de seus direitos. 
Para isso, visando contribuir com um pouco mais de informações sobre esse órgão, a presente pesquisa se valeu de uma metodologia focada na pesquisa bibliográfica descritiva, compilando o texto da lei e a visão de diversos doutrinadores acerca de temas afins, bem como apresentação de dados obtidos em matérias jornalísticas e entrevistas apresentadas pela própria gestão do órgão.

O presente trabalho foi organizado em dois capítulos principais. No primeiro, temos a apresentação da Procuradoria do Município do Recife, detalhando sua estrutura, a partir da Secretaria de Assuntos Jurídicos - órgão do governo municipal vinculado diretamente ao Gabinete do Prefeito, que exerce, em suma, a representação judicial e extrajudicial do Município, bem como oferece apoio ao Prefeito em assuntos de ordem jurídica e legislativa.

Em seguida, temos a Procuradoria Geral do Município do Recife - órgão central do sistema de assessoramento jurídico da Administração, vinculado à Secretaria de Assuntos Jurídicos, que tem por finalidade representar o Município, promovendo a defesa de seus interesses em qualquer que seja a instância judicial.

Por fim, apresentamos a Procuradoria Fiscal, ou Procuradoria da Fazenda Municipal subdivisão da Procuradoria Geral do Município do Recife (PGM) e, por sua vez, parte da Secretaria de Assuntos Jurídicos (SAJ), cuja função é cuidar das causas fiscais, buscando garantir ao Município a adimplência e maior arrecadação frente a seus contribuintes.

No capítulo seguinte, passamos a analisar a Procuradoria conhecendo as atividades desenvolvidas pelo Procurador Municipal, suas competências e prerrogativas, e sua importância para a sociedade. Aqui, apresentaremos também o lapso do constituinte de 88 em não incluir a advocacia pública municipal no texto da Magna Carta e a PEC no 17 de 2012, que busca sanar essa deficiência. Também apresentaremos as principais medidas adotadas pelo órgão perante a realidade do judiciário. O capítulo final, por conseguinte, traz a conclusão do trabalho, apresentado a visão do autor sobre a pesquisa desenvolvida.

\section{DA SECRETARIA DE ASSUNTOS JURÍDICOS DO MUNICÍPIO DO RECIFE}

\section{Função e estrutura}

A Secretaria de Assuntos Jurídicos do Recife (SAJ) é órgão do governo municipal vinculado diretamente ao Gabinete do Prefeito, que exerce, em suma, a representação jurídica, judicial e extrajudicial do Município e de suas entidades de Direito Interno, além de prestar apoio ao Prefeito 
em assuntos de ordem jurídica e legislativa. Suas funções incluem a redação de documentos e leis, além de atestar sobre contratos e convênios firmados pela Prefeitura, garantindo sua legalidade conforme os princípios que regulam a Administração Pública.

Sua figura máxima de gestão se caracteriza pelo Secretário de Assuntos Jurídicos, que, de acordo com o artigo 60, da Seção IV da Lei Orgânica da Cidade do Recife, é cargo de livre nomeação e exoneração pelo Prefeito. O Secretário atua, também, como Procurador Geral do Município (PGM), coordenando as procuradorias municipais (Fiscal, Judicial, Consultiva e a de Termos de Licitações e Contratos), sendo, desta forma, responsável em última instância por todos os processos em que a Prefeitura da Cidade do Recife (PCR) figura como parte.

A competência deste órgão, em linhas gerais, já se encontrava definida na Lei no 14.952/87 da Prefeitura do Recife, onde, em seu artigo 1ํ, declara que "compete exclusivamente à Secretaria de Assuntos Jurídicos a orientação jurídico-normativa dos órgãos e entidades da administração direta e indireta do Município", inclusive fundações instituídas ou mantidas pelo Poder Público Municipal ou que dele recebe recursos a qualquer título.

A mesma lei determina ainda, em seu art. 2o, parágrafo 1ํ, que "as funções de Procurador Geral do Município serão exercidas pelo Secretário de Assuntos Jurídicos"

Já em 1988, através do Decreto municipal 14.853/88, restou aprovado o Regimento Interno da SAJ e da Procuradoria Geral do Município, o qual disciplina suas respectivas organizações, atribuições, competências, inclusive de seus dirigentes, assessores e servidores em geral, além de fixar normas gerais de trabalho que orientam o funcionamento destes órgãos.

Em seu anexo I, no Título II, Capítulo I, firmou com seu art. 5o a finalidade e competências da SAJ no sentido de promover "a orientação jurídico-normativa dos órgãos e entidades da administração direta e indireta do Município" (inc. I), bem como "exercer, através de seus órgãos específicos, as atribuições de consultaria, representação do município, assessoria jurídica dos órgãos e entidades da administração direta e indireta, procuratório forense do Município", além de prestar "assistência judiciária aos servidores municipais, inclusive aos empregados da Administração Indireta" (inc. II); "a defesa dos direitos humanos" (inc. III), bem como "outras atribuições especialmente contidas pelo Prefeito" (inc. IV).

Ademais, estabeleceu, no Título III do Capítulo I, as competências do Secretário de Assuntos Jurídicos e de mais três importantes figuras na atuação deste órgão, quais sejam o Chefe de Gabinete, o Assistente do Secretário e os Oficiais de Gabinete. 
O Secretário de Assuntos Jurídicos, conforme já visto, é o pilar central da SAJ, cujas funções ficam bem definidas no art. 70 do Decreto, que determina suas funções como PGM, bem como "orientar, supervisionar e dirigir os serviços dos órgãos integrantes da Secretaria de Assuntos Jurídicos, praticando todos os atos inerentes ao seu cargo" (inciso I); Executar as competências da própria SAJ (inc. II), tendo garantidos, inclusive, poderes para remover servidores da Secretaria, caso necessário (inc. III). Também é seu dever elaborar a proposta orçamentária da Secretaria (inc. IV), e relatórios anuais das atividades praticadas pela SAJ (inc. V), bem como referendar os atos e negócios jurídicos praticados pelo Prefeito (inc. VI), garantindo a observância dos preceitos legais e morais de Direito Público.

O Gabinete do Secretário, por sua vez, tem como figura dirigente o Chefe de Gabinete, ao qual são garantidos "o exercício qualquer das atribuições inerentes ao Secretário de Assuntos Jurídicos, observadas as restrições legais, quando por expressa delegação deste" (art. 8o, inc. I). É seu dever, também, executar o encaminhamento dos processos oriundos do Gabinete do Secretário aos órgãos competentes (inc. II).

Quanto ao Assistente do Secretário, compete a este a supervisão da execução das tarefas administrativas (art. 9o, inc. I); manter atualizada a correspondência do Secretário, quanto aos assuntos internos e externos da SAJ (inc. II); preparar a agenda de compromissos e despachos do Secretário, submetendo-se à apreciação do Chefe de Gabinete e acompanhar o seu cumprimento (inc. III), além de executar outras tarefas correlatas a critério de Chefia imediata (inc. IV).

Por fim, à figura dos Oficiais de Gabinete compete colaborar na preparação de agenda do Secretário (art. 10, inc. I); "Receber e dar acesso ao Gabinete às partes que pretendem ser recebidas pelo Secretário e pelo Chefe de Gabinete" (inc. II), além de comparecer a eventos sociais, quando por determinação do Secretário (inc. III), e executar outras tarefas afins, a critério da Chefia imediata (inc. IV).

Essa formatação permaneceu até o fim do ano de 1996, quando foi sancionada a Lei municipal no 16.282/96, que passou a vigorar desde 1997, a qual reafirmava, no anexo VI, as competências da SAJ, acrescentando ainda: "realizar e julgar as licitações no âmbito da Administração Direta"; Também para "exercer as atividades extrajudiciais na formalização dos acordos, ajustes ou quaisquer atos ou negócios jurídicos que envolvam interesse da Fazenda Municipal, de forma direta ou indireta". Reforçou ainda sua atuação no campo das políticas sociais, instituindo-Ihe a competência para "apoiar e promover o exercício dos direitos de promoção da 
cidadania, prestando assistência judiciária, orientação nos assuntos de defesa do consumidor e na defesa dos direitos humanos".

Posteriormente, em 2005, através da Lei municipal no 17.108/05, que novamente reforçou as atribuições deste órgão, dando redação mais polida através do art. 9ำ, da Seção IV desta, buscou adequar-se aos princípios da Administração Pública vigente:

Art. 9o São atribuições da Secretaria de Assuntos Jurídicos:

I - Orientar e expedir atos jurídico-normativos, de observância obrigatória por todas as demais secretarias e órgãos e entidades da Administração Direta e Indireta do Município;

II - Exercer, através de seus órgãos específicos, as atribuições de consultoria e assessoria jurídica dos órgãos e entidades da Administração Direta e Indireta, bem como a representação legal do Município, judicial e extrajudicialmente;

III - exercer o controle preventivo da legalidade dos atos e negócios que, direta ou indiretamente, envolvam o interesse da Fazenda Pública municipal; IV - Controlar a legalidade das licitações no âmbito da Administração Direta e Indireta;

$\checkmark$ - Opinar em processos pertinentes a direitos, vantagens e deveres de servidores da Administração Direta e, quando couber, da administração indireta, inclusive em processos disciplinares;

$\mathrm{VI}$ - Promover a cidadania, apoiando o exercício de direitos individuais e coletivos, prestando assistência judiciária aos munícipes e defendendo os consumidores e os direitos humanos em interação com a Secretaria de Direitos Humanos e Segurança Cidadã.

VII - exercer outras atividades correlatas com as suas atribuições.

Vemos que, novamente, as competências restaram reafirmadas, reformulando-se o texto para adequá-lo melhor à própria evolução social do Direito.

\section{Organização da Procuradoria Geral do Município}

A Procuradoria Geral do Município do Recife é o órgão central do sistema de assessoramento jurídico do Município, vinculado à SAJ, conforme definido no artigo 6o do Anexo II, Título II, Capítulo I do Decreto № 14.583 de 1988. Tem por finalidade representar o Município, inclusive em Ação Civil Pública, promovendo a defesa de seus interesses em qualquer que seja a instância judicial, nas causas em que for parte, usando-se de todos os recursos legalmente permitidos e todos os poderes para o foro em geral. Também, em especial, recebe citação quando expressamente autorizado pelo Prefeito ou por delegação de competência. Propõe ações, desistências, transige, realiza acordos, recebe e dá quitação, bem como pode deixar de interpor recursos nas ações em que o Município figure como litigante (artigo 6으, I).

Revista de Direito da Cidade, vol. 09, no 1. ISSN 2317-7721 pp. 313-341 
Ademais, é de sua alçada a emissão de pareceres sobre questões jurídicas, fornecendo à SAJ o embasamento necessário à fixação de orientação jurídico-normativa dos órgãos e entidades da administração direta do município (inc. II); Exerce, ainda, a função de supervisão técnica das assessorias jurídicas e serviços de orientação ou apoio legal dos órgãos ou entidades da administração direta ou indireta municipal (inc. III); Examina a legalidade das inscrições de débito tributário na dívida ativa do Município, em especial quanto aos aspectos de liquidez e certeza, bem como inscreve débitos extratributários na dívida ativa, atuando inclusive na cobrança judicial dos débitos de qualquer natureza, inscritos na dívida ativa (inc. VIII), dentre outras funções mais específicas elencadas no referido artigo.

À época do Decreto 14.583, a estrutura da Procuradoria Geral do Município se ramificava nas seguintes divisões, conforme demonstra o quadro apresentado pelo Anexo II, Capítulo II, art. 70 do mesmo, disposto abaixo:

Art. $7^{\circ}$ A Procuradoria Geral do Município do Recife tem a seguinte estrutura organizacional:

10.6.1 - Subprocuradoria Extrajudicial

10.6.1.0 - GABINETE DO SUBPROCURADOR GERAL DO MUNICÍPIO

10.6.1.1 - Divisão de Termos e Contratos

10.6.1.2 - Divisão de Estudos Jurídicos

10.6.1.2.1 - Secção de Biblioteca

10.6.1.3 - Serviço de Processos Extrajudiciais

10.6.2 - Subprocuradoria Judicial

10.6.2.2 - Serviço de Controle de Processos

10.7.3 - Subprocuradoria de Contencioso de Pessoal

10.7.3.0 - GABINETE DO SUBPROCURADOR GERAL DO MUNICÍPIO

10.8.4 - Subprocuradoria Fiscal

10.8.4.0 - GABINETE DO SUBPROCURADOR GERAL DO MUNICÍPIO

10.8.4.1 - Divisão das Execuções Fiscais

10.8.4.1.1 - Serviço de Controle de Processos

10.8.4.2 - Setor de Dívida Ativa

Assim, podemos entender que a mesma se dividia nos seguintes subprocuradorias: Extrajudicial - à qual faziam parte o Serviço de Processos Extrajudiciais, a Divisão de Termos e Contratos e a Divisão de Estudos Jurídicos, na qual, por sua vez, estava a Secção de Biblioteca; Judicial - com o Serviço de Controle de Processos; Contencioso de Pessoal; e a Fiscal - na qual figuravam a Divisão de Execuções Fiscais, o Serviço de Controle de Processos e o Setor de Dívida Ativa.

Cada subprocuradoria contava com um Subprocurador Geral, como cargo comissionado pelo Prefeito, por indicação do próprio Procurador Geral, entre os procuradores alocados em cada divisão. A estes, era instituída a função de chefia sobre a referente Subprocuradoria Especializada, 
cabendo reportar-se periodicamente ao Procurador Geral a respeito de suas atividades e resultados.

Essa estrutura permaneceu até o ano de 1991, quando por força de nova lei, foi reformulada para uma organização otimizada e mais adequada aos interesses da Administração.

\section{Linhas gerais sobre a Procuradoria da Fazenda Municipal do Recife}

A Procuradoria Fiscal do Município do Recife é subdivisão da Procuradoria Geral do Município do Recife e, por sua vez, parte da Secretaria de Assuntos Jurídicos. Sua função é cuidar das causas fiscais, buscando garantir ao Município a adimplência e maior arrecadação de seus contribuintes. Para tanto, conta com o apoio de três unidades administrativas básicas: 1 - O Setor de Dívida Ativa (STDA), ao qual compete o recebimento de petições em massa e ajuizamento das Execuções Fiscais; 2 - A Divisão de Execução Fiscal, à qual compete a representação do município frente ao judiciário; 3 - A Seção de Controle de Processos (SCP), responsável pela organização, controle e distribuição dos autos aos Procuradores Municipais.

A história desse órgão teve início em 1987, através da Lei no 14.952 da Prefeitura do Recife, a qual aprova o regimento interno da SAJ e da PGM. Em sua estrutura, contava com a figura das Subprocuradorias Judicial - a qual tinha por finalidade exercer a função procuratória forense nas áreas cível e patrimonial, e Extrajudicial - a qual tinha função de exercer consultoria jurídica de qualquer matéria afeta à Procuradoria Geral; de Contencioso de Pessoal - a qual competia a função procuratória sob o foro trabalhista, e, por fim, a Subprocuradoria Fiscal - objeto central de nosso estudo, cuja atribuição é exercer o procuratório forense na área fiscal.

Nessa organização, a Secretaria de Assuntos Jurídicos já possuía como órgão central a Procuradoria Geral do Município, onde o próprio Secretário da SAJ exercia a função de Procurador Geral do Município, o qual orienta, supervisiona e dirige os serviços dos órgãos integrantes da Procuradoria Geral.

A Subprocuradoria Fiscal, por sua vez, era dirigida pelo Subprocurador Geral, cargo de livre escolha, nomeação e destituição pelo Prefeito, por proposta do Procurador Geral do Município dentro os procuradores judiciais integrantes do quadro funcional. Desde essa formatação, já contava com o auxílio da Seção de Controle de Processos, Setor de Dívida Ativa e da Divisão de Execução Fiscal.

Foi no ano de 1991, através da Lei no 15.508 da Prefeitura do Recife que, em seu artigo 1으 substituiu o termo "Subprocuradoria" pela atual nomenclatura "Procuradoria", tendo, nessa 
ocasião, sido extinta a Subprocuradoria de Contencioso de Pessoal, e suas atribuições, partilhadas com Procuradorias Judicial e Extrajudicial.

Dessa forma, a nova estrutura da Procuradoria Geral era subdividida em Procuradorias Judicial e Extrajudicial, e Fiscal. Também o cargo de Subprocurador Geral foi modificado para Procurador-Chefe, mantendo-se as mesmas competências.

Assim iniciou a atual formação da Procuradoria Fiscal do Município do Recife, em cuja competência encontram-se a fiscalização e, quando necessária, a execução dos débitos fiscais dos quais os tributos originários estão definidos no artigo 4ํ do Código Tributário Municipal, sendo eles: 1 - Impostos Sobre Serviços de qualquer natureza (ISS); 2 - Imposto sobre a Propriedade Predial e Territorial Urbana (IPTU); 3 - Imposto sobre a transmissão onerosa "intervivos" de bens imóveis e de direitos a eles relativos (ITBI); 4 - Taxas de funcionamento e limpeza pública; 5 Contribuição de melhoria.

Para a consecução de tal, a PFM conta com uma equipe, atualmente, de 19 procuradores, todos concursados, que buscam garantir a realização das finalidades deste órgão, tão vital para a Administração. Além destes, a PFM conta com servidores de carreira, concursados e terceirizados, além de assistentes e estagiários, os quais auxiliam os procuradores na realização das tarefas afins.

Conta também com duas varas especializadas no Judiciário, quais sejam a 1a e 2a Vara dos Executivos Fiscais Municipais, competentes para processar e julgar, com exclusividade, as ações e execuções relativas à cobrança da dívida ativa, tributária e não tributária, oriundos do Município do Recife, buscando a máxima eficácia da interação entre as máquinas judiciária e executiva.

\section{DA PROCURADORIA DA FAZENDA MUNICIPAL DO RECIFE}

\section{A importância da Procuradoria Fiscal do Município e a omissão do constituinte de 1988}

Dentre os muitos poderes do Estado, destaca-se a capacidade de tributar, cuja origem advém de contribuição que era oferecida, seja em ouro, escravos ou qualquer outra espécie, por um povo vencido em sinal de dependência aos vencedores - o tributo. Atualmente, contudo, tal "oferta" é feita de forma diferente, sendo regida, delimitada legalmente e atribuída pelo Estado em suas margens legitimadas por força da Constituição e das normas de Direito Público.

Sua função, de forma simplificada, é prover subsídios ao Estado para a realização de suas funções vitais e garantia dos direitos fundamentais de todo cidadão, característico do Estado Social 
Fiscal: Social, pois fundamenta seus objetivos na consecução dos Direitos Sociais Fundamentais positivados pela Lei Maior; e Fiscal, pois a tributação, ou o fisco, torna-se a principal fonte de captação de recursos para a manutenção deles.

Sobre isso, em seu artigo "A Finalidade da Tributação e sua Difusão na Sociedade", Viol declara: "indubitavelmente, a finalidade primordial da tributação é o financiamento do Estado, pois sem recursos o Estado não pode exercer suas atribuições mínimas".

Impor o tributo, neste sentido, significa restringir a capacidade econômica do indivíduo para a garantia dos direitos do coletivo. Para que isso seja legítimo, como vimos, é necessário que tal poder emane do Estado com função de promover o bem-estar social comum e garantir os direitos fundamentais. Ainda, na visão de Viol, "pelo fato de a tributação estar na origem do convívio social, do bem comum e do Estado, ela não pode estar dissociada da moralidade, dos valores que a sociedade preza"

Visualizando melhor a estrutura desse Estado, vemos que nosso país é uma República Federativa, a qual é formada pela União, estados e municípios. O exercício do poder é, desta forma, atribuído a órgãos distintos e independentes, os quais são submetidos a um sistema de controle para garantir o cumprimento das leis e da Constituição. Por isso, entendemos que o espírito do legislador brasileiro visava a busca por uma maior autonomia dos membros federativos, delimitando suas competências e estabelecendo os parâmetros para seu funcionamento.

O municipalismo brasileiro, segundo Fabriz e Ferreira (2002, p. 104), "com a carta constitucional de 1988, passou a constituir uma entidade federal dotada de auto-organização, com governos próprios e competências exclusivas". Tal visão denota a importância que foi conferida ao poder executivo no âmbito municipal.

No tocante à matéria tributária, resta no próprio texto da Constituição de 1988, em seu artigo 30, que compete aos Municípios legislar sobre assuntos de interesse local (inc. I), bem como instituir e arrecadar os tributos de sua competência, e aplicar suas rendas (inc. III). O que resta confirmado, nos mesmos termos, na Lei Orgânica do município do Recife, em seu artigo 6o.

Assim, vemos o quanto fica caracterizada a autonomia, não apenas em seu caráter financeiro, mas também sociopolítico, perante a liberdade legislativa do ente municipal sobre a matéria tributária e da aplicação de seus fundos arrecadados na infraestrutura de si mesmo. Nesse contexto, confirmam Fabriz e Ferreira (2002, p.109) que, desse modo, "a autonomia municipal vem no bojo da descentralização político, administrativa e financeira, repartida entre a União, Estados- 
Membros e Municípios" e que a mesma está "alicerçada em princípios que norteiam os preceitos positivados que lhe concedem legitimidade para se auto organizarem".

Torna-se clara, então, a importância do poder exercido pelos órgãos de controle fiscal, dotados da capacidade de orientar o contribuinte, bem como buscar o resgate de tributos não pagos: assim surge a figura da Procuradoria Fiscal, órgão do poder Executivo vinculado à Procuradoria Geral do Município e à Secretaria de Assuntos Jurídicos, cuja atividade especializada é a representação jurídica do município em sede fiscal. Sua atividade permite o resgate dos valores da Dívida Ativa tributária de volta aos cofres públicos, no intuito de garantir a promoção das políticas públicas da Administração e defesa dos direitos fundamentais.

Apesar do movimento municipalista e de sua vitalidade para o Poder Público, quando passamos a analisar a Constituição Federal de 1988, em seus artigos 131 e 132, que tratam da Advocacia Pública, não vemos menção, de forma explícita, da figura do Procurador Municipal:

Art. 131. A Advocacia-Geral da União é a instituição que, diretamente ou através de órgão vinculado, representa a União, judicial e extrajudicialmente, cabendo-lhe, nos termos da lei complementar que dispuser sobre sua organização e funcionamento, as atividades de consultoria e assessoramento jurídico do Poder Executivo.

$\S 1$ O Omissis;

$\S 20$ Omissis.

$\S 3$ 3o Na execução da dívida ativa de natureza tributária, a representação da União cabe à Procuradoria-Geral da Fazenda Nacional, observado o disposto em lei.

Art. 132. Os Procuradores dos Estados e do Distrito Federal, organizados em carreira, na qual o ingresso dependerá de concurso público de provas e títulos, com a participação da Ordem dos Advogados do Brasil em todas as suas fases, exercerão a representação judicial e a consultoria jurídica das respectivas unidades federadas.

Parágrafo único. Omissis.

Tratando disso, Motta (2014), afirma que a norma mandatória de criação de uma advocacia pública municipal como implícita no texto da Carta Magna, vez que a criação de órgão especializado para versar da representação jurídica e extrajudicial é imprescindível para as atividades do ente federativo municipal, pois, segundo ele, "[...] a advocacia pública não é restrita aos estados-membros, eis que também para o terceiro ente federativo - o município -, é imprescindível que tenha o órgão a representá-lo judicialmente e dar-lhe consultoria e assessoramento jurídico".

Portanto, enquanto ao nível estadual e federal a criação da Advocacia Pública é norma mandatória expressa, ao município a criação desta é implícita. E sob qual modelo deve ser criada a 
Advocacia Pública Municipal? Por óbvio que pelo modelo advindo dos artigos 131 e 132 da Constituição que amplamente estudamos anteriormente.

A PEC no 17 de 2012

Sobre a omissão legal supracitada, corre às contas do Senado Federal a Proposta de Emenda à Constituição № 17, de 2012, a fim de alterar a redação do art. 132 da Constituição Federal, estendendo aos Municípios a obrigatoriedade de organizar carreira de procurador. Esta PEC, a qual já foi aprovada em dois turnos na Câmara e encontra-se atualmente à Secretaria Geral da Mesa, enfrentou certa resistência. A última proposta Emenda, assinada pela Senadora Ana Amélia, foi no sentido de restringir a obrigatoriedade da carreira de Procurador para municípios de maior porte - mais de cem mil habitantes.

Os argumentos apresentados por ela são, em suma, o elevado custeio de uma procuradoria para os municípios de menor porte, além da sobreposição da influência da figura do Procurador diante da vontade do gestor público. Segundo a Senadora, "[...] as previsões da proposição seriam prejudiciais aos 3.100 (três mil e cem) municípios de menor população, nos quais o procurador seria único e, no mínimo, exerceria suas atividades por longo período de tempo". Para ela, esse funcionário poderia tornar-se, "em pouco tempo, um ditador da esfera local", submetendo o prefeito que assumisse o cargo às suas normatizações, nem sempre mais adequadas ou de melhor interesse de acordo com o entendimento do gestor público eleito.

Acrescenta ainda que, no âmbito financeiro, a presença do Procurador nestes municípios representa uma ameaça ao erário, vez que a remuneração deste agente público criaria mais uma casta a "corroer" os cofres públicos municipais. Assim, conclui a Senadora com a defesa de que a presença de uma Procuradoria seria válida apenas em municípios de grande porte, onde haveria uma pluralidade de agentes no cargo, formando um corpo de profissionais voltados à prática de suas atribuições.

Face a esse entendimento, o Senador Inácio Arruda, relator do parecer no 534 de 2014CCJ, concluiu pela rejeição dessa proposta de emenda, arguindo que o exercício da atividade procuratória em âmbito municipal é indispensável e fundamental no exercício da autonomia administrativa, bem como na defesa dos interesses de sua referente esfera federativa. De acordo com ele, "a criação da carreira de procurador de município é fundamental, não apenas para garantir autonomia funcional, mas se alcançar a imparcialidade, qualidade e eficiência na representação judicial e consultoria jurídica dos municípios", vez que a inclusão dos municípios 
como entes federativos promovida pela Constituição Federal de 1988, implica no reconhecimento de sua capacidade de auto-organização, governo próprio e competências exclusivas, e "nesse aspecto, é fundamental o assessoramento jurídico especializado, qualificado e independente, o que só se atinge com um corpo jurídico isento, cujo ingresso no serviço público municipal se dê mediante concurso público".

Concluiu o Senador que a aprovação da PEC no 17, de 2012, constituirá "um passo decisivo para se alcançar tais objetivos, bem como o fortalecimento municipal", de forma que tal regulamentação não pode ser restrita aos municípios com população superior a cem mil habitantes, ou seja, cerca de trezentos municípios.

Ainda, no tocante aos argumentos de elevado gasto com os agentes públicos, rebateu o Senador Inácio Arruda que a remuneração deste funcionário fica a cargo de dispositivo legal do próprio município, de acordo com sua capacidade financeira, e que não há vinculação entre o piso salarial desta carreira com outras afins:

Conclui ainda, o Senador, sobre a alegação de sobreposição de influências que a existência de um procurador com vínculo efetivo com a Administração "permitirá que seja preservada a memória jurídico-institucional do município", bem como que sejam selecionados "servidores altamente capacitados, mas que responderam administrativamente caso descumpram os deveres legais".

Podemos, com isso, compreender ainda que a importância do Procurador para a sociedade reflete a própria indispensabilidade da figura do advogado para o próprio Estado Democrático de Direito. De acordo com a redação do art. 133 da Constituição, "O advogado é indispensável à administração da justiça, sendo inviolável por seus atos e manifestações no exercício da profissão, nos limites da lei". O mesmo é reforçado pelo contido no caput do artigo 2ㅇda Lei 8.906/94 - o Estatuto da Ordem dos Advogados do Brasil, que reafirma o texto anterior: "o advogado é indispensável à administração da justiça [...]".

Assim, em havendo, de fato, a implementação da PEC 17/2012, teremos a previsão constitucional impondo à administração municipal a criação de uma Procuradoria organizada, com servidores concursados, sujeitos às normas e princípios da Administração Pública.

Resta discutir a questão quanto da equiparação salarial deste cargo aos outros afins, na esfera Estadual e Federal. Fato é que esta PEC não determina piso salarial para essa carreira, cabendo isso à legislação municipal, não restando determinado qualquer tipo de equiparação obrigatória aos Procuradores Estaduais ou Federais. 
Da remuneração dos Procuradores Municipais no Recife

No Município do Recife, a remuneração dos procuradores está definida na Lei №. 17.788 de 2012, que em seu anexo V, traz a tabela de vencimentos dos Procuradores Judiciais, a qual varia entre $R \$ 8.536,03$ e $R \$ 8.954,47$. Além destes valores, a Lei prevê, no artigo 30, duas gratificações: Gratificação de Atividade de Procurador (GAP) e Gratificação de Verba Honorária (GVH), que são valores calculados sobre o total de honorários arrecadados pelos Procuradores, e divididos entre eles.

Questiona-se aqui quanto à forma como essas gratificações são pagas, uma vez que um procurador que tenha atuado com melhor performance, e arrecadado maior montante de honorários à Fazenda perceberá o mesmo valor que um procurador que, por qualquer que seja o motivo, não tenha arrecadado honorário algum. A opção do legislador municipal em não instituir um critério de proporcionalidade no rateio dessas gratificações acaba por se tornar um estímulo à acomodação do funcionalismo público, haja vista que, independente do quanto um se empenhe em ganhar causas, seu vencimento será o mesmo, e ainda poderá receber sobre os honorários às custas do trabalho de outros procuradores.

Por outro lado, se considerarmos um critério de proporcionalidade entre os valores das causas distribuídas a cada procurador, isso poderia gerar discussões internas do "porque tal procurador recebeu tal causa", ou "porque as causas de fulano têm maior valor que as minhas". Analisando por essa perspectiva, podemos ter a noção de que o intuito do legislador, nesse caso, foi de evitar conflitos internos por conta das distribuições das causas, em especial, das de alto valor. A forma de distribuição das gratificações, hoje, visa garantir maior isonomia entre a atuação dos funcionários, sem favorecer um determinado procurador perante o outro.

\section{A prática da advocacia privada}

Outro ponto importante a ser tratado, que foi excluído da discussão quanto à regulamentação da atividade do Procurador Municipal pela PEC 17/2012, é referente à possibilidade ou não da prática da advocacia no âmbito privada pelo Procurador Municipal. Analisando a Procuradoria do Recife, uma vez que estes agentes obedecem ao Estatuto dos Funcionários Públicos Municipais (Lei № 14.728 de 1985), não há nenhum tipo de vedação à prática da advocacia privada para estes agentes, salvo quando em cargo de comissão com dedicação exclusiva.

Revista de Direito da Cidade, vol. 09, no 1. ISSN 2317-7721 pp. 313-341 326 
Sobre esse assunto, a Seccional da Ordem dos Advogados do Brasil do Distrito Federal (OAB/DF) emitiu parecer em favor do direito de os advogados públicos atuarem na esfera privada, desde que não atuem contra o Poder Público. De acordo com o Parecer no 13/2015 da OAB-DF, segundo o artigo 10 do Estatuto da Advocacia e da $O A B$, "o exercício da profissão de advogado compreende a postulação a órgão do Poder Judiciário e as atividades de consultoria, assessoria e direção jurídicas", realizando essa atividade tanto os advogados vinculados a cargos públicos quanto os particulares.

Ademais, declara o Parecer que a condição profissional de advogado, devidamente inscrito na $\mathrm{OAB}$, aplicável ao advogado público, encontra-se expressamente prevista no parágrafo primeiro do art. 3o do referido Estatuto, o qual, em termos, sujeita ao regime deste, além do regime próprio a que se subordinem, os integrantes da Advocacia Pública.

De acordo com o entendimento do Estatuto, o exercício da Advocacia no âmbito privado pelos detentores de cargo público não experimenta obstáculo senão das atribuições inerentes ao cargo público ocupado, salvo quanto aos Procuradores Gerais, Advogados Gerais, Defensores Gerais, bem como os dirigentes de órgãos jurídicos da Administração Pública, os quais são "exclusivamente legitimados para o exercício da advocacia vinculada à função que exerçam, durante o período da investidura" (artigo 29). Também, por força do artigo 30, os advogados públicos são impedidos de exercer atividade "contra a Fazenda Pública que os remunere ou à qual seja vinculada a entidade empregadora".

Consolidado nestes dispositivos e através da influência direta do comando constitucional do art. 5o, inciso XIII, que impõe ao exercício da advocacia condição de direito fundamental, conclui a OAB-DF que "simples critérios de conveniência, [...] carregados de subjetivismo, postos em qualquer sede normativa, não possuem legitimidade jurídica para inviabilizar o exercício da advocacia".

Como argumento, a Seccional acrescenta que "entendimento diverso viabiliza inaceitáveis ofensas ao princípio da isonomia", vez que "titulares de cargos públicos vinculados a outras profissões [...] não estão proibidos dos respectivos exercícios profissionais para além do serviço público". Além disso, profissionais vinculados a outras carreiras públicas, que não as jurídicas, mas devidamente inscritos na OAB pode exercer atividade de advogado, observando aos impedimentos do artigo 30 do Estatuto da Ordem. Por fim, porque, através de entendimento diverso do apresentado, podem restar criados segmentos dentro da própria advocacia pública que permitam advogar fora do serviço público, ao passo que outros segmentos não teriam a mesma prerrogativa. 
Com isto, teríamos "um quadro surreal de castas de advogados, na mesma situação, onde uns são mais advogados do que outros".

No tocante aos Procuradores Municipais do Recife, uma vez que não há na legislação qualquer impedimento, aos Procuradores do Município do Recife é permitida a prática da advocacia em âmbito privado, observado o disposto no Estatuto da Advocacia e da OAB.

\section{O Procurador Municipal, sua atuação e as principais medidas pela PFM}

Como visto, o Procurador Municipal é, em sua natureza, um advogado público, com poderes incumbidos no sentido de orientar a chefia do Poder Executivo na formulação de leis e projetos, bem como exercer a própria representação processual do município, frente às causas em que for parte.

Compreender essa atuação, como ocorre em vias de fato, é importante para a compreensão da realidade processual brasileira. Discute-se muito sobre a reforma do Código e a reformulação de leis já desvalidas pelo tempo, contudo, por vezes, esquecendo que as máquinas executiva e judiciária são operacionalizadas por pessoas físicas, seres humanos, dotados de discernimento e compreensões diversas sobre os institutos aplicados ao caso prático. Não adianta reformular a legislação se não for dada a devida atenção aos aplicadores processuais, compreendendo melhor suas dificuldades na práxis. É visando elucidar um pouco mais essa questão, que passamos a estudar mais detalhadamente as atribuições dos Procuradores Municipais, com atenção à Procuradoria Fiscal do Recife.

O exercício da função de Procurador incorre em prestar assessoria jurídica em todas as áreas de atividade do Poder Público municipal, judicial e extrajudicialmente, sugerindo e recomendando, no que for necessário, providências visando resguardar os interesses e dar segurança aos atos e decisões da Administração Pública, bem como acompanhar todos os processos de interesse da municipalidade, tomando, quando necessário, as providências para salvaguardar os interesses do Estado.

Nesse sentido, incumbe-lhe também o poder de postular em juízo em nome da própria Administração, propondo ações e apresentando contestações, além de avaliar provas auferidas e realizar audiências. Esta representação nos autos judiciais ocorre em quaisquer instâncias ou esferas onde a Administração for parte, seja ré, autora, assistente, opoente ou interessada de qualquer outra forma. 
Cuida também, o Procurador, em caráter extrajudicial, de mediar conflitos, assessoramento em negociações e, se necessário, propositura das defesas e recursos aos órgãos competentes.

É função sua, inclusive, providenciar a análise dos contratos firmados pelo município, realizando a avaliação dos riscos que o mesmo possa envolver, visando garantir segurança jurídica e a observância dos princípios do Direito Administrativo nas relações jurídicas estabelecidas entre o ente público e terceiros. Quando necessário, recomenda, inclusive, procedimentos internos a fim de conservar a observância dos princípios regentes da legalidade, publicidade, impessoalidade, moralidade e eficiência nas atividades da Administração.

Esta última foi reforçada com o advento da Lei no 8.666, de 1993, que estabelece as normas para a realização de licitações e contratos da Administração Pública. Com isso, passa a ser também função do Advogado Público Municipal, na figura do Procurador, analisar tais processos, garantindo assim a observância dos princípios norteadores, do interesse da Administração e do respeito aos direitos garantidos pela Carta Magna.

Sobre esse tema, afirmam Corrêa, Martins e Pelosini (2012) que "[...] é em âmbito local que se dá efetiva e diretamente a implementação de políticas públicas". Por esta razão, dá-se o destaque e importância da advocacia pública no âmbito municipal, pois "cabe a ela viabilizar mediante prévio crivo de legalidade a concretude de tais medidas políticas". Destacam ainda que "não podemos olvidar, outrossim, que a atuação do advogado público não está limitada à representação do município em juízo", pois a função da Procuradoria Municipal é, a priori, preventiva, vez que também é sua "a missão constitucional de controle de legalidade mediante a atividade consultivo-preventiva, como órgão de balizamento e orientação jurídica para todos os órgãos da administração pública", constitucionalmente vinculada aos princípios do Direito Administrativo.

Quando passamos a analisar a estrutura da Procuradoria do Município do Recife, podemos perceber que, para garantir máxima eficácia no desempenho de suas funções, foram criadas divisões desse órgão, segmentando-o através de uma distribuição de competências específicas para cada membro, especializando seus funcionários em ramos delimitados de atuação - assim, tem-se a ramificação da Procuradoria Geral em três fases: a Procuradoria Judicial, Extrajudicial e Fiscal - esta última, objeto central de nosso estudo. Conforme já desenvolvido anteriormente, incumbe a esta, na pessoa de seus procuradores, representar o município nas causas fiscais em que for parte. 
Para isso, a Procuradoria Fiscal conta com o trabalho de dezenove procuradores, todos admitidos por meio de concurso público, além da atuação de servidores de carreira e terceirizados, que colaboram com o trabalho destes, e dois setores especializados - a Seção de Controle de Processos (SCP), responsável pela distribuição das publicações e processos para os procuradores, e o Setor de Dívida Ativa (STDA), que trata do recebimento de petições em massa e ajuizamento da execução fiscal.

Além destes, atuam em conjunto com a Procuradoria Fiscal dois outros órgãos: Secretaria de Finanças (SEFIN) e a Empresa Municipal de Informática (Emprel).

No curso do processo fiscal, a SEFIN é o órgão da Administração Pública responsável por exercer a Administração Tributária, realizando o lançamento, bem como o controle, a cobrança e a arrecadação de tributos municipais. Uma vez que o tributo se encontra em atraso, é responsabilidade deste órgão buscar, pelas vias administrativas, o pagamento do mesmo. Contudo, quando não se faz possível dessa forma, a Secretaria realiza a inscrição na dívida ativa, com a emissão da Certidão de Dívida Ativa (CDA), remetendo a mesma à Procuradoria Fiscal para prosseguimento da cobrança pelas vias judiciais, através da Execução Fiscal.

O trâmite desse processo administrativo de cobrança durava, em média, três anos. Contudo, devido a mudanças internas na busca pela maior eficiência, esse prazo foi reduzido para seis meses, desde o final do ano de 2014. Logo, basta um semestre de inadimplência para que o devedor seja inscrito em dívida ativa. Uma vez efetuada a inscrição, a cobrança deixa seu trâmite administrativo e encontra seu viés judicial através da atuação dos Procuradores Municipais.

Atualmente, segundo dados informados pela Associação dos Procuradores Municipais do Município do Recife (APMR), o montante da dívida atual da cidade é de seis bilhões de reais, dos quais, a meta estipulada pela gestão da PFM é recuperar cento e oitenta milhões. Já no primeiro trimestre do ano de 2015, houve um crescimento de $25 \%$ no valor recuperado da dívida ativa, comparado ao ano de 2014. Esse valor passou de trinta milhões para, aproximadamente, trinta e oito milhões.

Para isso, a PFM aposta em um pacote de ações, dentre as quais estão a aperfeiçoar a utilização da penhora on-line nas contas-correntes através do sistema Bacenjud e a penhora de veículos, pelo Renajud, reforçando o pleito destes em juízo. Visa também intensificar o parcelamento dos débitos judiciais realizados pela internet, além do envio de cartas aos contribuintes, fornecendo já a primeira via do parcelamento. Busca também a realização de leilões de imóveis com débitos de IPTU.

Revista de Direito da Cidade, vol. 09, no 1. ISSN 2317-7721 pp. 313-341 
Com essas medidas, a gestão almeja mais celeridade no trabalho dos Procuradores Fiscais, com a consecução de melhores resultados para o resgate dessa dívida ativa.

\section{As prerrogativas de função dos procuradores municipais e o Novo Código de Processo Civil}

Já esclarecemos a importância do tributo para o Estado. Por esta razão, uma atenção especial é dada ao processo que versa das causas tributárias. Quando analisamos a figura da Fazenda Pública como parte no processo judicial, devemos entender que a mesma se encontra na defesa de interesses difusos, não dos seus de forma particular. Dessa forma, o processo de execução fiscal instaurado pelo procurador municipal não está buscando saciar o desejo pessoal do administrador, mas o resgate dos recursos que servem para a manutenção da própria sociedade. Sobre isso, Santos e Lamblém (2010), afirmam:

Outro aspecto apontado é que quando a Fazenda Pública atuar em juízo estará defendendo o erário. Na verdade, todo o conjunto de receitas públicas não é de responsabilidade, na sua formação, do governante, pois será formada com a contribuição de toda sociedade. A autoridade pública será mera administradora dessa massa de recursos arrecadados.

Por esta razão, são garantidas à Fazenda Pública uma série de prerrogativas para o melhor desempenho de suas funções. Dentre estas, destacaremos cinco: foro especializado, isenção de custas, prazos diferenciados, intimação pessoal e reexame necessário. Vaz (2013) reforça a necessidade destas, vez que considera que o "Estado é um ente complexo e nada mais plausível que entender que a decisão do legislador em atribuir a ele prerrogativas processuais decorre da real necessidade, não de um mero favorecimento".

\section{Do foro especializado}

Quando falamos de foro especializado, referimo-nos à reserva feita no próprio Código de Organização Judiciária do Tribunal de Justiça de Pernambuco de varas exclusivas à Fazenda Pública Municipal, a quem, de acordo com os termos do artigo 80 deste código, "compete [...] processar os executivos fiscais, seus incidentes e ações acessórias". Isso garante que uma atenção especial seja auferida aos processos de execução, não desviando o foco do juízo para causas diversas. 
Da isenção de custas

Outra prerrogativa processual existente é quanto à isenção de custas para a Fazenda Pública. Tal se encontra definido nos termos do art. 4, inciso I da Lei no 9.289, de 1996.

Sobre esse tema, declaram Santos e Lamblém (2010) que "[...] não faz sentido algum ela própria [União Federal] pagar custas para a justiça federal, já que é do orçamento da União como um todo que se retira o necessário para sua manutenção". Afirmam ainda que, no caso do Estado, também não seria razoável pagar custas na justiça estadual, vez que, em última análise, "sua justiça é ele próprio". Assim, "a única opção do legislador foi referente à Fazenda Pública Municipal que ele resolveu, visando um tratamento isonômico entre as Fazendas, isentar, no que diz respeito a custas e emolumentos".

Dos prazos e da intimação pessoal

O Novo Código de Processo Civil estipula prazo em dobro para os representantes da Fazenda Pública, tanto para contestação quanto para recurso, tal qual consta no artigo 183: "A União, os Estados, o Distrito Federal, os Municípios e suas respectivas autarquias e fundações de direito público gozarão de prazo em dobro para todas as suas manifestações processuais, cuja contagem terá início a partir da intimação pessoal. [...]".

Alteração evidenciada, em relação ao Código de Processo Civil de 1973, que modificou a proposta do prazo em quádruplo para contestação, tornando-se, assim, ambos os prazos duplicados. As modificações não se resumem à mera redução de um dos prazos - a contagem e o termo inicial de contagem também foram alterados, passando a serem computados da intimação pessoal, podendo esta ser feita por meio de "carga, remessa ou meio eletrônico" (parágrafo 1o). Tal modificação visa dar maior fluidez aos processos e facilitar a contagem dos prazos, de acordo com o princípio da celeridade do poder judiciário.

O Superior Tribunal de Justiça se manifestou, ainda, acerca do Agravo Regimental neste tribunal: a Súmula no 116, define que "a Fazenda Pública e o Ministério Publico têm prazo em dobro para interpor Agravo Regimental no Superior Tribunal de Justiça".

Do reexame necessário, ou duplo grau de jurisdição

O reexame necessário é independe de requerimento por parte do procurador do ente público, União, Estados, Distrito Federal ou Municípios. 
O reexame necessário, embora fundamentado no ideal de proteger o erário de possíveis vício na elaboração da sentença, esta prerrogativa, da maneira em que era regulamentada do CPC de 1973, em seu artigo 475 (quando determinava a obrigatoriedade de se remeter a sentença proferida contra a Fazenda Pública ou que julgue procedente os Embargos à Execução de dívida ativa da Fazenda, ao Tribunal hierarquicamente superior àquele que a proferiu, com intuito de buscar a confirmação da mesma pela instância superior para que, só então, a decisão produza efeitos), colocava em cheque a celeridade do processo e a confiabilidade nas decisões, levando os tribunais a um acúmulo de execuções. Com objetivo de melhorar esse ponto, o Novo Código trouxe uma reformulação dessa prerrogativa, impondo maiores restrições ao reexame em seu artigo 496. Agora, a Remessa Necessária ocorrerá apenas para a condenação ou o direito controvertido for de valor certo não excedente a quinhentos salários mínimos para municípios que sejam capitais e cem salários para os municípios menores, bem como no caso de procedência dos embargos do devedor na execução de dívida ativa do mesmo valor.

Tais alterações reduziram o alcance do instituto, diminuindo consideravelmente o influxo processual a retornar às mãos do tribunal para nova análise.

\section{As Varas dos Executivos Fiscais Municipais}

Atualmente, temos em Recife duas Varas dos Executivos Fiscais Municipais, ambas localizadas no Fórum Desembargador Rodolfo Aureliano, onde, segundo informações do Conselho Nacional de Justiça, tramitam cerca de dois milhões de ações.

Desde o mês de abril de 2015, estas varas contam com o Processo Judicial Eletrônico (PJe). A adoção deste sistema nas Varas de Execuções Fiscais de Recife objetiva a redução da sobrecarga processual nas unidades, vez que esse modelo diminui de forma significativa a burocracia no Judiciário, garantindo a celeridade no andamento das execuções e ampliando o acesso à Justiça, além de facilitar o gerenciamento do processo, proporcionando inclusive economia de papel e reduzindo as rotinas no âmbito do Judiciário. Com isso, magistrados e advogados podem acessar os autos destas ações de qualquer localidade através da internet, e mesmo peticionar por meio dela. Essas facilidades também beneficiam as partes, que podem consultar os autos pela internet, sem a necessidade de ir até a unidade judiciária.

Visando priorizar as Execuções, estas varas têm adotado um regime diferenciado, almejando a redução do acúmulo de processos nas mesmas. Intensificando a utilização do sistema Bacenjud, medida que teve início desde o ano de 2014. 513 bloqueios em contas-correntes já 
foram realizados, envolvendo cerca de $\mathrm{R} \$ 2,5$ milhões no período de janeiro a junho de 2014, segundo informações divulgadas em matéria "Priorização de execuções fiscais no TJ-PE ajuda prefeitura de Recife", publicada pelo site Consultor Jurídico em 30 de agosto de 2014, em processos referentes à cobrança de Imposto sobre Propriedade Predial e Territorial (IPTU) e Imposto Sobre Serviços (ISS), representando um aumento de 115\% comparado ao ano de 2013, sendo a maior arrecadação desde o ano de 2009.

Em nota, informa ainda o site que "O trabalho nas Varas de Executivos Fiscais envolve a identificação de processos prontos para sentença, daqueles que já prescreveram, das ações que estão abaixo da norma municipal”. Esta norma municipal refere-se à Portaria no 299 de 2009, que prevê o valor mínimo de R\$ 1 mil para que a Prefeitura ajuíze a Execução Fiscal. "Também prevê a identificação de pequenos, médios e grandes devedores. Além dos bloqueios realizados, as decisões proferidas arquivaram, só neste ano (2014), 71.380 processos".

Além destas, outra medida tomada com intuito de agilizar o processo de execução foi uma parceria realizada entre o Tribunal de Justiça de Pernambuco e a Prefeitura do Recife, os quais firmaram um acordo para agilizar a citação das partes. A partir de agora, as citações das partes nas Execuções Fiscais serão emitidas pela própria Prefeitura. Estima-se que sejam feitas cerca de três mil citações mensais. A medida tem como objetivo agilizar o trâmite processual, não sendo mais as citações encaminhadas individualmente pelas Varas de Executivos Fiscais, mas passando a serem geradas e postadas em larga escala pela Prefeitura, que usará listagens mensais encaminhadas pelas unidades judiciárias. Essa parceria também poupará o Judiciário dos custos com o envio das cartas pelos correios. De acordo com a juíza Ana Luíza Câmara, coordenadora do Regime Especial instaurado nas Varas dos Executivos Fiscais Municipais, a Prefeitura poderá ser ressarcida desse valor ao final do processo.

Também em abril de 2015 foi realizado pelo Tribunal um mutirão especial que contou com o apoio de 40 servidores, para organizar o acervo já existente das Varas de Execuções Fiscais. O trabalho foi divido em sete etapas: identificar de processos prontos para sentença e separá-los dos já prescritos e das execuções que não se enquadram com a Portaria 299 de 2012; e identificar e separar os pequenos, médios e grandes devedores. Como resultado, cerca de quarenta mil processos já foram arquivados por esta ação, desbastando estas varas para que possam receber e dar melhor atenção a novos processos.

A última etapa dessa ação, segundo o CNJ, consiste na criação de uma Central de Conciliação com Núcleo de Execuções Fiscais, que visa pôr o contribuinte em negociação direta 
com a Fazenda, nos moldes dos juizados especiais, buscando através da negociação prevenir que o processo venha à fase de execução, e agilizando o trabalho do judiciário.

Diante disto, vê-se a preocupação com o processo de Execução Fiscal, e o esforço desempenhado pelos diversos órgãos em tornar o processo o mais eficiente possível para garantir o retorno aos cofres públicos dos valores em cobrança, e evitar em um futuro próximo que os contribuintes voltem a permanecer em inadimplência.

\section{O impacto da Dívida Ativa sobre as políticas públicas e a sociedade}

Pelo já explanado, o tributo é a base financeira do Estado Democrático de Direito. É através dele que são captados os recursos necessários para a manutenção da infraestrutura do ente federado, bem como a garantia da prestação dos serviços básicos à população na defesa de seus direitos fundamentais.

Tributar é, assim, ato legitimado e limitado pelo legislador constituinte que constringe a capacidade financeira do indivíduo, devendo, por isto, obedecer aos parâmetros estabelecidos pela Lei Maior, com intuito único e exclusivo de promover o bem-estar da sociedade. Qualquer tributo que seja instituído fora deste intuito transcende a legitimidade do poder estatal, ferindo as garantias constitucionais e a dignidade do homem.

Devido à sua natureza, a contribuição fiscal deve ser clara, transparente e objetiva ao contribuinte, a fim de que o mesmo possa ser consciente de seu papel transformador na sociedade. É, pois, através do cumprimento com sua parcela no fisco que prosseguir para com as obras e políticas sociais se faz possível.

Quando buscamos visualizar isso no âmbito municipal é que a importância dessa contribuição se torna ainda mais notável, pois é nele que o efeito das políticas públicas é mais sentido pela população. Cada ato da gestão é perceptível à coletividade de uma forma muito mais ampla do que nos âmbitos federais e estaduais, tornando assim a transparência quanto a aplicação da receita fiscal ainda mais imprescindível.

Nesse cenário, também se torna muito mais sensíveis os efeitos da inadimplência por grande parcela da sociedade. A falta do cumprimento com a carga contributiva é tão prejudicial às contas públicas e aos atos da gestão quanto a própria corrupção e desvios de verba. A diferença é que não se veem manifestações de iniciativa popular contra o sonegador quando este é oriundo do próprio seio da sociedade. 
Conforme apresentado, há no município do Recife uma enorme dívida ao erário, no valor de aproximadamente seis bilhões de reais. Valor este que deveria estar sendo aplicado em obras sociais, na construção e reforma de escolas, hospitais, estradas, ou mesmo da segurança pública e na melhoria e revitalização dos bairros e ruas da cidade. Ao invés disso, encontra-se em litígio nos armários, mesas e prateleiras de nosso já tão atribulado sistema judiciário.

A cada dia que estes processos permanecem, a cidade sofre, esquecida, no clamor silente das vozes dos hipossuficientes abandonados em leitos de hospitais públicos, quando há leito, e crianças à espera de uma educação que tarda e não chega pela falta de professor, livro, caderno, cadeira etc.

Muito se fala dos nossos governantes, apontado falhas e faltas, tantas quantas podemos achar ou criar. Mas o quanto se fala sobre a própria falta da população em honrar seu quinhão na construção de uma sociedade mais justa e igualitária?

Nesse cenário, a importância da figura do Procurador Municipal se torna clara, vez que é responsabilidade sua lembrar a população de seu dever, e agir em nome da sociedade na busca pela justiça. Ser Procurador significa, nesse sentido, ser instrumento do povo, para o povo, tanto quanto um vereador ou prefeito. Mais que isso, ser Procurador Municipal é ser, ao mesmo tempo que advogado público, um agente político transformador da sociedade, orientando a administração na observância dos princípios de Direito.

Além disso, compete à sua função agir no resgate dos valores devidos ao erário, garantindo à administração a arrecadação dos fundos necessários para a manutenção da máquina estatal, conscientizando também a população de sua parcela devida na promoção do Estado Social.

Para isso, o Procurador conta com o auxílio de diversos órgãos especializados e prerrogativas garantidas pela própria legislação para maior eficácia de suas atividades, visando a máxima celeridade das Execuções, almejando resgatar a maior parcela possível da Dívida Ativa.

Apesar de sua importância inegável para a sociedade, a figura dos procuradores e da Procuradoria Municipal ainda é muito ignorada pela doutrina e pela própria sociedade. Prova disso se faz pela dificuldade, durante a realização deste trabalho, em encontrar textos doutrinários que versassem sobre o assunto.

A Procuradoria do Município do Recife é uma das mais antigas do Brasil, tendo sua origem em um regimento anterior à própria Constituição Federal, que permanece quase inalterado senão por poucas atualizações frente o advento da própria evolução do Direito, mantendo-se funcional 
até o presente. Mesmo assim, nenhum estudo mais aprofundado foi encontrado sobre esse órgão, tão vital à Administração Pública.

Pelo contrário, várias omissões quanto a esse órgão foram demonstradas no terceiro capítulo, como a própria falta da Constituição em regimentar a carreira de procurador municipal, como o fez com a AGU e as Procuradorias Estaduais.

Nos últimos anos, apenas, tem-se visto um maior esforço em busca da valorização deste órgão, com o movimento realizado pela Associação Nacional dos Procuradores Municipais pela aprovação da PEC no 17, de 2009, que regulariza a situação deste órgão face à Constituição. Também, um maior esforço realizado pelo Judiciário em parceria com a Administração Pública buscando aproximar o contribuinte e o Procurador para uma mais célere solução dos conflitos.

A criação de uma Central de Conciliação com Núcleo de Execuções Fiscais demonstra esse desejo de estreitar os laços entre os agentes representantes da Fazenda e a sociedade, deixando claro que ainda há muito o que se fazer no sentido de conscientizar a população de seu papel como contribuintes, não apenas no sentido do Direito Tributário, mas de contribuintes sociais.

Além disso, há um forte lapso no que tange a campanhas informativas sobre a real situação da Dívida Ativa ao público. É importante que a população conheça este montante e esteja ciente de sua participação nas contas do erário. Se é de interesse do povo saber o que é feito com seu dinheiro, também deve ser de seu interesse saber o que não foi feito pela falta dele! E talvez assim poderemos intensificar os movimentos sociais em busca de uma sociedade mais justa e consciente de seu papel na erradicação das desigualdades sociais.

\section{CONCLUSÃO}

O Constituinte de 1988 trouxe ao município maior autonomia sobre sua organização e regulamentos, facilitando a aplicação e implementação de políticas públicas que resguardem os direitos sociais com a aplicação das verbas arrecadadas por meio dos tributos. Para garantir essa arrecadação, é necessária, como vimos, um órgão competente bem estruturado.

No município do Recife, essa função cabe à Procuradoria da Fazenda Municipal, subdivisão da Procuradoria Geral do Município especializada na representação do ente municipal frente as Execuções Fiscais em que for parte, através dos Procuradores Municipais.

Através do presente trabalho, podemos entender que as atividades destes não se limitam apenas às de um advogado público, estendendo-se a agentes políticos, participando do processo 
de elaboração de políticas públicas e fiscalizando a atividade estatal na garantia da observância dos princípios da Administração Pública.

Atuam, assim, judicial e extrajudicialmente, na construção de uma sociedade mais igualitária e justa, na busca da satisfação dos direitos e garantias fundamentais elencados pela Carta Magna. Isso nos permite ter uma melhor visão dos agentes processuais, numa perspectiva que prioriza a compreensão da atuação humana sobre o processo face às discussões de reforma da legislação. Não devemos nos esquecer que a lei, por mais vital que seja ao Estado Democrático de Direito, é instituto fictício, mera ilustração da realidade. Se o desejamos, por tanto, modificar o cenário atual da justiça brasileira, precisamos compreender também quem são os atores que figuram nesse quadro, e como agem, para que passemos a modificar também as pessoas, e não apenas a letra dos códigos.

Embora de suma importância para a sociedade e a Administração, contudo, estes agentes públicos são ainda olvidados pela doutrina e pelo próprio Estado. O trabalho destes agentes carece de maior divulgação e valorização, incentivando sua atuação nos meios sociais e reforçando a luta pelos direitos fundamentais.

Pudemos ainda visualizar o esforço implementado pelo poder público para fortalecer a aproximação entre o contribuinte e a Procuradoria, com a idealização da Central de Conciliação com Núcleo de Execuções Fiscais. Apesar disso, ainda há pouca movimentação no sentido de tornar a atuação da Procuradoria mais visível, divulgando informações da situação fiscal da cidade. Talvez seja necessário que se implementem esforços nesse sentido, para chamar a atenção do contribuinte e aproximá-lo da Administração, tornando-o mais consciente de sua participação na transformação da sociedade.

\section{REFERÊNCIAS BIBLIOGRÁFICAS}

ASSOCIAÇÃO dos Procuradores Municipais do Recife. Marcos Vinícius de Morais assume a chefia da Procuradoria da Fazenda do Recife. Disponível em <http://apmrecife.org.br/marcos-vinicius-demorais-assume-a-chefia-da-procuradoria-da-fazenda-do-recife>. Acesso em 18 de julho de 2015.

PFM prorroga desconto de até $90 \%$ para pagamentos de dívida do IPTU e ISS. Disponível em $\overline{<\mathrm{http}: / / a p m r e c i f e . o r g . b r / p f m-p r o r r o g a-d e s c o n t o-d e-a t e-90-p a r a-p a g a m e n t o s-d e-d i v i d a-d o-i p t u-e-~}$ iss>. Acesso em 18 de julho de 2015.

BRASIL. Constituição Federal de $1988 . \quad$ Disponível em <http://www.planalto.gov.br/ccivil_03/constituicao/ConstituicaoCompilado.htm>. Acesso em 20 de setembro de 2015. 
Lei no 13.105, de 16 de março de 2015. Código de Processo Civil. Disponível em <http://www.planalto.gov.br/ccivil_03/_Ato2015-2018/2015/Lei/L13105.htm>. Acesso 02 de setembro de 2015.

Lei no 5.869, de 11 de janeiro de 1973. Código de Processo Civil. Disponível em $<$ http://www.planalto.gov.br/ccivil_03/leis/L5869compilada.htm>. Acesso em 02 de setembro de 2015.

Lei no 8.906, de 4 de julho de 1994. Estatuto da Ordem dos Advogados do Brasil. Disponível em <http://www.planalto.gov.br/ccivil_03/Leis/L8906.htm>. Acesso em 20 de setembro de 2015.

Ordem dos Advogados do Brasil do Distrito Federal. Parecer no 13 de 2015. Brasília, DF. 21 de maio de 2015.

Senado Federal. Proposta de emenda à constituição no 17, de 2012. Autoria: Deputado Maurício Rands. Disponível em <http://www25.senado.leg.br/web/atividade/materias//materia/105021>. Acesso em 12 de agosto 2015.

BUENO, Cássio Scarpinela. Novo Código de Processo Civil Anotado, Saraiva, 2015

CIANCI, Mirna. A remessa necessária no novo código de processo civil. In: ARAÚJO, José Henrique Mouta; CUNHA, Leonardo Carneiro da. Advocacia Pública. Coleção Repercussões do Novo CPC, V. 3. Salvador: Editora Juspodivm, 2015.

CONSELHO Nacional de Justiça. Varas de Execuções Fiscais de Recife adotam Processo Judicial Eletrônico. 27 de abril de 2015. Disponível em: <http://www.cnj.jus.br/noticias/cnj/61098-varasde-execucoes-fiscais-de-recife-adotam-processo-judicial-eletronico>. Acesso em 18 de julho de 2015.

CONSULTOR Jurídico. Priorização de execuções fiscais no TJ-PE ajuda prefeitura de Recife. Revista Consultor Jurídico. 30 de agosto de 2014. Disponível em <http://www.conjur.com.br/2014-ago30/priorizacao-execucoes-fiscais-tj-pe-ajuda-prefeitura-recife>. Acesso em 12 de agosto de 2015.

CORRÊA, Rafael Gomes; MARTINS, Maria Carolina e PELOSINI, Ortiz. Advocacia Pública Municipal é fundamental. Consultor Jurídico. 01 de julho de 2012. Disponível em <http://www.conjur.com.br/2012-jul-01/advocacia-publica-municipal-fundamental-aplicacaojustica>. Acesso em 12 de agosto de 2015.

CUNHA, Leonardo Carneiro da. A Fazenda Pública em juízo. 11ae ed. São Paulo: Dialética, 2013.

FABRIZ, Daury Cesar e FERREIRA, Claudio Fernandes. O Município na Estrutura Federativa Brasileira. Revista da Faculdade de Direito da Universidade de Minas Gerais. Minas Gerais; n. 41. 2002. Disponível em: <http://www.direito.ufmg.br/revista/index.php/revista/article/view/1230> Acesso em 08 de agosto 2015.

FRANCO, Marcelo Veiga. Câmaras de mediação e conciliação na Fazenda Pública: o artigo 174 do Novo Código de Processo Civil como contribuição para o acesso à justiça "desjudicializado". In: ARAÚJO, José Henrique Mouta; CUNHA, Leonardo Carneiro da. Advocacia Pública. Coleção Repercussões do Novo CPC, V. 3. Salvador: Editora Juspodivm, 2015.

MOTTA, Rauder Cavalcante. A (in) compreendida advocacia pública municipal. Revista Eletrônica do Ministério Público do Estado de Goiás. Goiás; n. 27. 16 de junho de 2014. Disponível em: 
<http://www.mp.go.gov.br/revista/pdfs_6/Artigo3_final_Layout1.pdf>. Acesso em 01 de agosto 2015.

PERNAMBUCO. Lei Complementar no 100, de 21 de novembro de 2007. Código de Organização Judiciária de Pernambuco. Disponível em: <http://www.tjpe.jus.br/downloads/downloads.asp>. Acesso em 20 de junho de 2015.

RECIFE. Código Tributário do Município do Recife. Disponível em $<$ http://www.recife.pe.gov.br/pr/secfinancas/portalfinancas/uploads/pdf/Informacoes_Tributarias/ INFORMACOES_CTM_SEM_LEI.pdf>, acesso em 10 de abril de 2015.

Decreto $\quad$ № 14.583 de $1988 . \quad$ Disponível em

<http://www.legiscidade.recife.pe.gov.br/decreto/14583/>, acesso em 10 de abril de 2015.

Lei $N^{\circ} 17.788$ de 2012. Disponível em < http://www.legiscidade.recife.pe.gov.br/lei/17788/>. Acesso em 14 de outubro de 2015.

Lei № 14.728 de 1985. Estatuto dos Funcionários Públicos do Município do Recife. Disponível em < http://www.legiscidade.recife.pe.gov.br/lei/14728/>. Acesso em 14 de outubro de 2015.

Lei № 14.952 de 1987. Disponível em <http://www.legiscidade.recife.pe.gov.br/lei/14952/>, acesso em 10 de abril de 2015.

Lei № 15.508 de 1991. Disponível em <http://www.legiscidade.recife.pe.gov.br/lei/15508/>, acesso em 10 de abril de 2015.

Lei № 16.282 de 1996. Disponível em <http://www.legiscidade.recife.pe.gov.br/lei/16282/>, acesso em 12 de maio de 2015.

Lei № 17.108 de 2005. Disponível em <http://www.legiscidade.recife.pe.gov.br/lei/17108/>. Acesso em 19 de junho de 2015.

Lei Orgânica do município do Recife. 04 de abril de 1990. Disponível em <http://www.legiscidade.recife.pe.gov.br/lei/organica/>. Acesso em 19 de junho de 2015.

SANTOS, Fabiana dos e LAMBLÉM, Gláucia Aparecida da Silva Faria. A aplicação do princípio da isonomia processual entre o particular e a fazenda pública. Anais do SCIENCULT. Mato Grosso do $\begin{array}{lllllll}\text { Sul. } & \text { v. } & 5 & & \text { n. } 2010 . & \text { (5). } 2 \text { Disponível }\end{array}$ <.http://periodicos.uems.br/novo/index.php/anaispba/article/viewfile/321/249>. Acesso em 30 de julho de 2015.

VAZ, Heydi Soares. O tratamento diferenciado da fazenda pública em juízo mediante análise do atual código de processo civil e do projeto de lei para o novo código. Jurisway. 2013. Disponível em <http://www.jurisway.org.br/v2/dhall.asp?id_dh=11884>. Acesso em 30 de julho de 2015.

VIANA, Juvêncio Vasconcelos. Efetividade do processo em face da fazenda pública. São Paulo: Dialética, 2003.

VIOL, Andréa Lemgruber. A Finalidade da Tributação e sua Difusão na Sociedade. Disponível em < http://www.receita.fazenda.gov.br/Publico/estudotributarios/Eventos/Seminarioll/Texto02AFinalid adedaTributacao.pdf> Acesso em 05 de junho de 2015.

ZENKNER, Marcelo. O (velho) reexame necessário no Novo CPC. In: ARAÚJO, José Henrique Mouta; CUNHA, Leonardo Carneiro da. Advocacia Pública. Coleção Repercussões do Novo CPC, V. 3. Salvador: Editora Juspodivm, 2015. 
Revista de Direito da Cidade

vol. 09, ำ 1. ISSN 2317-7721

DOI: 10.12957/rdc.2017.25241

Trabalho enviado em 24 de agosto de 2016.

Aceito em 13 de setembro de 2016.

Revista de Direito da Cidade, vol. 09, № 1. ISSN 2317-7721 pp. 313-341 